\title{
Research on the Training Model of Double-Qualified Teachers
}

\author{
Zhixiong Xiao \\ School of Management \\ Wuhan Yangtze Business University \\ Wuhan, China
}

\author{
Bei Qin \\ Decoration School \\ First Vocational Education Center of Wuhan \\ Wuhan, China
}

\begin{abstract}
With the rapid development of China's higher vocational education, it is imperative for higher vocational colleges to raise high-quality double-qualified teachers. Above all, this paper introduced four kinds of foreign training models of double-qualified teachers. They are American model, German model, Japanese model and Ukraine model. Then the four kinds of training models were analyzed and compared. Finally, this paper put forward four kinds of training models based on the actual situation of China: the training model of schoolenterprise cooperation, the college training model, the schoolbased training model and the model of teacher self-training, and gave the system suggestions on the training of double-qualified teachers.
\end{abstract}

Keywords-double-qualified teachers; training model; revelation

\section{INTRODUCTION}

China has become a global manufacturing country, but the shortage of skilled workers with high quality in production line become one of bottlenecks for China into the powerful manufacturing country in the world. The way to break the bottleneck is vocational education. The higher vocational colleges and universities is the cradle for training high skilled talents in China, and talent training lies in the teachers. The characteristics of vocational education and the demand of talents of enterprise development together determine that the vocational education must cultivate practical talents. To achieve this goal must fully play the center role of doublequalified teachers. At present, the proportion of doublequalified teachers in most vocational college is far away from the state's $70 \%$. So strengthening the training of doublequalified teachers is specific practices for schools to change the traditional "theory teaching" to " practice teaching", is a inevitable choice for the school to adapt the talent demand of enterprise.

\section{The Connotation of Double-Qualified Teachers}

The concept of double-qualified teacher is no unified definition because the time when double-qualified teacher is raised is not long. Through summarizing the relevant academic point of view, this paper thinks that double-qualified teacher is the teacher who has a set of ordinary teachers' quality and engineers' quality, is the teacher who can be engaged in professional theoretical teaching and guide the skill training, is the teacher who is both a disseminator of knowledge and a model of practical skills, is a high quality and double professional and technical titles teacher in both theory and practice [1] [2].

Specifically, double-qualified teachers should include three aspects of abilities. The first is the teaching ability. Doublequalified teachers must have a solid theoretical foundation, be competent for the teaching of the specialized course, and familiar with the content of the course. They must also have the ability to write course syllabus, guide professional practice and graduation design teaching. They must skillfully use modern teaching technique and have the basic ability of education and teaching management. The second is the research ability. Double-qualified teachers must undertake integrated curriculum development, actively explore vocational teaching law and educational reform. The third is the professional practice ability. Double-qualified teachers must have certain practical ability and innovative development ability [3].

\section{The Foreign Training Model of Double-Qualified TEACHERS}

\section{A. American Model}

The vocation technology education in America implements teacher certification system. Whether ordinary education, vocation technology education or adult education, American teachers' qualification standards are very high. Vocational education teachers must be bachelor's degree graduates or postgraduates, and have received the professional training of educational college and practice link. The teacher must attend the teacher qualification examination every two and a half years and obtain the teaching qualified certificate. The teacher management is very strict. The teachers whose teaching is irresponsible or whose teaching quality is poor will be dismissed. Social status and salary of teachers is relatively high, economic income is only after the doctor. Similarly, there are very strict requirements to the part-time teachers. The part-time teacher must have master degree or above and must be outstanding engineers and technical experts in the industry. In addition, America attaches great importance to the coordination of before-position training and after-position of vocational teachers, execute "occupation technology education teacher certification", and implements teacher certification system for the vocation technology education. 


\section{B. German Model}

Germany implements lifelong vocation teacher. The professional standard of vocation education teacher is higher in Germany. The vocation technology education teachers in Germany must have received higher education, have more than 5 years of service, master educational and psychological science, and pass special state exams in order to obtain a qualification certificate. The vocation school teachers are divided into theory teachers, general education teachers and practice teachers in Germany. Theory teachers and general education teachers are not eligible until they have completed four to five years of formal university education and have passed the engineer qualification examination at university graduation or the state examination. Practice teachers must not only pass the engineer qualification examination or the first state examination, but also experience two to three years of business practice. The most teachers must still pass their master's examination and the second national examination before they become formal vocational school teachers.

\section{Japanese Model}

The double-qualified teachers in Japan are known as vocation training instructor. It is double profession teacher who have double bachelor in technology profession (mechanical, electrical, household appliance repair etc.) and education profession. They are mainly engaged in professional skills training in vocation high school, college, university and public vocational training institutions. The vocational training instructor is a kind of vocational qualification. The training institutions of vocational education teacher are vocational ability development universities in Japanese. The universities have established a long course of four years and a short course of six months. The long courses of four years for high school graduates train the teachers with high theoretical knowledge, strong professional skills and teaching ability. The short course of six months is provided for the persons with professional skills and practical experience. The learners are asked for more than two years of practical work experience or the same level of skill, and need pass the national two level skills examination.

\section{Ukraine Model}

Double-qualified teachers are known as engineer teacher. They is trained by the engineering normal education system in Ukraine. Ukraine Engineering Education College put forward the model of " $4+1$ ". The model is that 4 years' engineering college graduates need to add 1 year of the psychological and educational training. "Double Certificate" refers to the academic certificate and technical certificate. The training levels include junior professionals, Bachelor of vocational education, talents, Master of Education. Educational content include general education courses, vocational orientation courses and professional courses. The way of training is mainly the school education. Teacher training target in different levels of schools have different positioning [4].

\section{A COMPARATIVE ANALYSIS OF THE ForEIGN TRAINING MODEL OF DOUBLE-QUALIFIED TEACHERS}

Four models above have different characteristics. The Characteristics of American model is high qualification standards and strict process management. This training model is a lot of pressure for teachers, but also makes the overall quality of teachers maintain at a high level. The premise is the teachers must be given preferential treatment. The degree of specialization of German model is high. They attach great importance to the practice of enterprise and divide the course into theory course, general education course, profession practice course. Different courses are taught by different teachers. Thus the double-qualified teacher in the German model is a group concept, rather than an individual concept. The Japanese model insists on double certificates and focus on the teacher's vocation characteristics. The double-qualified teachers must have the double degree of technology profession and teacher profession. The Ukraine model also adheres to the double certificates. Compared with the Japanese model, this model is more attention to profession, only 1 years of teacher vocational quality training [5].

\section{The Revelation Foreign Training Model to Our COUNTRY}

Through the analysis of foreign training model of doublequalified teachers, we find that the key of teachers training is to strengthen the skills training. Therefore, to strengthen the cooperation of school and enterprise is an important way to train the double-qualified teachers. But only the training model of school-enterprise cooperation can't meet the needs of college for double-qualified teachers. The school also should make full use of their resources, mobilize the enthusiasm of teachers, the boldly explore the college training model, the school-based training model and the model of teacher selftraining.

\section{A. Training Model of School-enterprise Cooperation}

The template The training of school-enterprise cooperation is the effective model in the training of double teacher quality in Higher Vocational College. Vocational college teachers engaging in the production practice, technology development, product design in the cooperative enterprise can be familiar with the production and operation process, understand the latest technical information, and have the opportunity to consult the relevant experienced technical staffs, widen theory vision, improve the practice ability, promote teachers change from single teaching to double-qualified teachers. Paid training on teachers in higher vocational colleges by using advanced equipment and real production management environment of large and medium-sized enterprises is a kind of form of school-enterprise cooperation that can be chosen. Vocational colleges can also use their own scientific and technical advantage and assign some teachers to chair or participate in the enterprise production, construction, management, applied technology research, advanced technology promotion or scientific research, technical innovation, the research and development of new products and new technology. According to the state 
policies on the vocational education development, professional teachers must have the practice of two months in enterprises every two years. Training the teachers' professional practice ability in the real work conditions also belongs to the training model of school-enterprise cooperation.

\section{B. The College Training Model}

College training model is traditional teacher training model that has been generally recognized in Chinese vocational education. This model fully plays the advantages of teachers and technical resources in various teacher training bases and colleges and universities to train the professional teachers in higher vocational colleges. At the undergraduate level, nation selects outstanding graduates of higher vocational schools to take a more advanced course of study or training by entrance examination and arranges them back to the higher vocational school when they graduate. At the graduate level, the nation encourages double-qualified teachers in the vocational school in-service studying for master degree to improve their academic level and scientific research ability and optimize the structure of teachers of vocational education. The college training model is more suitable for China's national conditions. At present, the key of this model is to update the training content, focus on job training, strengthen the training of professional skills. Only in this way, double-qualified teachers can fully develop.

\section{The School-based Training Model}

The school-based training model is mainly implemented by Higher Vocational Colleges based on the development need of teachers' self-ability. The colleges use the campus training factory, training base, laboratory to train teachers' practical teaching ability. For teachers from enterprises, their practical experience is rich, but the theoretical teaching experience is lack. So it is necessary to develop their teaching methods and teaching practice. For the expertise and professional characteristics of young teachers, the higher vocational colleges should also choose professional academic and technology leaders to improve the double quality of young teachers as soon as possible. The schoolbased training model can not only flexibly arrange the activity time and the content according to the actual conditions, greatly reduce the economic burden of teachers and schools, improve the continuing education benefits.

\section{The Model of Teacher Self-training}

Teacher self-training refers that teachers in Higher Vocational Colleges independently determine the direction of vocational development, independently set training contents and independently choose the promotion means of double quality according to the professional development based on the completion of the teaching task [6]. Teachers get the vocational qualification certificate or technical grade certificate that meets the requirements of vocational development and helps to improve the teaching ability through independent study and examination. This is the effective method to enhance the double quality of teachers in higher vocational colleges. Schools agree with the premise, teachers independently contact the enterprise closely related with the profession as part-time and social service also is the effective forms of mode. In the training model, teachers are given a high degree of autonomy, schools supervise and reward the teachers on the basis of the corresponding performance standards.

\section{Suggestions on the System of Double-Qualified TEACHERS TRAINING}

The stability and development of any society must rely on a set of rules to adjust and maintain. Training and the construction of double-qualified teachers in higher vocational colleges need fundamentally to strengthen the system construction.

\section{A. Establishing the Qualification Certification System of Double-qualified Teachers}

Because the vocational education in our country started late, the construction of double-qualified teachers is in the stage of early standardization. Our country can draw lessons from the foreign certification system experience of doublequalified teachers, combines with China's reality and establishes as soon as possible the certification system of double-qualified teachers in our country vocational education by the education administrative department. This is the core of the construction of double-qualified teacher team [7]. Due to the requirements of professional teachers' double quality in vocational education, professional teacher in vocational education must have teacher qualification certificate and professional qualification certificate based on the statutory education. This is the most basic conditions as professional teachers in vocational education. In national unified certification standards of double-qualified teachers, education department sets up specialized management institutions to regularly carry out the evaluation and identification of doublequalified teachers.

\section{B. Improving the Training System of School-enterprise Cooperation}

Firstly, the relationship between government , industry, enterprise, school must be straightened out, their respective rights, obligations and responsibilities must be clear, coordinated unified regulations system of higher vocational education must be set up. Secondly, the local government should enact incentive policies, such as tax incentives, financial subsidies, special funds, to improve the enthusiasm and initiative of enterprises to participate in teachers' training of vocation education.

\section{Improving the Training System of Double-qualified Teachers}

On the one hand, school should draw up medium and long term training plan for the teachers in their school. The school should especially establish a guiding and inspiring mechanism for teacher's post training in the enterprise in order that taking part in the practice of enterprise become the conscious action of teachers. On the other hand, schools need to establish a set of perfect training system and employment 
system for part-time teachers and undertake the training and evaluation for part-time teachers.

\section{Reforming the Evaluation System of Double-qualified Teachers}

Fair and just evaluation system for teachers needs to be established. The evaluation forms include school evaluation, industry evaluation, teaching supervision evaluation and student evaluation. The evaluation results should be associated with the post responsibility of full-time teachers and the class hour allowance of part-time teachers. At the same time, incentive mechanism of double qualified teachers should be established. The teachers with double qualifications can preferentially participate in teaching guidance and textbook compilation, prior undertake education and teaching research, prior be recommended to study hard masters or doctors degree. Moreover, the guiding role of professional title evaluation should be played. The school should establish the professional title evaluation standard of double-qualified teachers and make the skills assessment as the main index of professional title evaluation [8]. The demonstration effect will continue to inspire teachers' positivity of self training and self enhancement.

\section{ACKNOWLEDGMENTS}

This paper is supported by The National Social Science Fund of China (12CTQ033), Humanities and Social Science
Research Project of Hubei Provincial Department of Education (2010b305), Educational Science Planning Project of Hubei Province (2010B277), Research Project of Wuhan Yangtze Business University (S2013002).

\section{REFERENCES}

[1] Milo Hadwin, Economic Globalization and Higher Technical Education: A Philosophical Approach, International Forum on Higher Vocational and Technical Education, 2003, pp.312-317.

[2] DaS,A.K, Internationalization of Higher Education, Society for Research into Higher Education, vol.47, pp.5-11, 2001.

[3] Rongying Huang. The construction of doublequalified teachers of higher vocational education based on system level, Journal of Guilin Normal College, vol.23, pp.139-142, January 2009.

[4] Yan Ma, Mingxing Zhou. Training model of double-qualified teachers in Japan and Ukraine, Vocational Technology Education, vol.25, pp.6869, December 2004.

[5] Shasha Yang. The comparison of foreign training model of doublequalified teachers and its enlightenment to China, Adult Education, pp.95-96, June 2007.

[6] Yuliang Liu, Online Education as an Effective Alternative Strategy for Higher Technical Education, International Forum on Higher Vocational and Technical Education, 2003, pp.372-384.

[7] Yingxia Lu. Study on the construction of double-qualified teacher teams, City Economy in China, pp.188-189, February 2011.

[8] Zhaojing Chen. Research on the training ways of double-qualified teachers, Science Technology and Industry, vol.9, pp.164-165, January 2010 